\title{
ACHIEVING SECURITY, REDUCING TENSIONS: NIGERIA AND STRATEGIC STABILITY IN THE DECADE AHEAD
}

\author{
U. Joy Ogwu \\ NIIA Lagos
}

\section{Introduction}

Nation states invariably seek security and in the rapidly changing international environment of today, it is essential that states, developing states in particular, begin to look ahead to the consolidation of their own forces and resources for the maintenance of safety, peace and security. This is even more so at a time of resurgence within the international system, of divisive forces detrimental to the continued maintenance of peace, stability and security within today's world community.

Our devotion towards our subject is attributable to a number of specific currents. First, the belief which has gained credence over the recent past that instability and insecurity in the developing world would of necessity have reverberations on the security and stability of the international system. A second factor, is of course the fact that security and instability in the developing nation states invariably arise from direct superpower and or major-power intervention. This form of intervention is most often anticipatory or pre-emptive in the sense that one super-power intervenes for fear that another super-power may intervene in the conflict and thereby reap what it perceives as the accruing benefits. The third factor is related to resources and food security. It is a widely held assumption that interventions are essentially a function of the degree of scarcity of vital raw materials. These strategic resources assume such major importance especially when instability in the areas where they .are exploited develops to such a point that a real threat does exist to the continued maintenance of their supply line.

It is in this context that this writer discusses the perpetuation of minority rule in Namibia and South, Africa. The problems in these two areas remain basically unresolved because of the entrenched interests of the Western world in exploiting the mineral deposits in the territories. While maintaining public opposition to racial repression, the Western allies have firmly integrated South Africa into their economic and military systems. Controlling the Cape Route and possessing vast deposits of minerals that are essential to modern industry, South Africa enjoys NATO protection and is linked to the Western Defence system through plans like the Project Advokaat. Apart from the military umbrella, the Western nations, particularly France, West Germany and the United States are instrumental' in giving South Africa a nuclear capability. Economically, Western investments and non- 
restrictions policy have kept the South African economy and industrial base strong and confident. In sum, South Africa's extra-ordinary raw materials, the strategic significance of the Cape Route, as well as a large reservoir of cheap labour provide, to a great extent, the bases of Western attraction to this bastion of racism. It is clear that this conflict situation has reverberations on the domestic environment of contiguous African nations and other countries like Nigeria. This means that African nations must devise urgent strategies for self-reliance, relying on their own forces - economic, political, military to implement and enforce their basic objectives for survival.

In their debates on the appropriate mechanisms for solving these security problems, African geopoliticians have identified a broader scope for security: an urgent need for a unified economic planning; long-range planning for political stability in Africa: the need for a unified foreign economic policy and diplomacy, and a unified military and defence strategy. Implicit in these strategies is the fact that security entails more than Military security. Its political as well as economic dimensions are of critical importance as they represent a spectrum of factors that aggravate the threat and challenges to Security. The following pages will address the multidimensional nature of security and stability with particular reference to Nigeria and Black Africa.

The history of the first twenty-seven years of Nigeria's policy was that the country had well-formulated national interests in view and strove unflinchingly to defend those interests. The core interest of Nigeria was the augmentation of Nigeria's power in all his dimensions and security of Nigeria's national interests. Nigeria's, enduring stance on apartheid, decolonization and economic self-reliance not only enhanced her influence among developing nations, it also secured for her international diplomatic support in the campaign against South Africa and in the decolonization process.

The ultimate goal in this paper is not to review Nigeria's role in optimising its national interests, but rather to explain the problems that threaten Nigeria's security and stability in the context of its Africa centred policy. In the process of the ensuing analysis, Nigeria's strategies for combating the forces of destabilization will become evident.

II

The serious issues of security and stability within Africa have for years dominated African debates. There are probably four problem areas demanding mechanisms for maintaining peace and security in Africa, namely: fear of external aggression or intervention by extra-regional powers; internal conflicts within member states leading to forced changes or fear of forced changes; conflicts between member-states particularly, those related to boundaries inherited from the Colonial rulers; and the Southern Africa question including the threat 


\section{Annals of the Social Science Council of Nigeria}

posed by the military might of South Africa and its "perceived impact on the Liberation Movements and the Frontline States.

Since the founding of the OAU in 1963, African leaders have debated the appropriate mechanism for solving these security problems. Suggestions have included: the urgent need for a unified economic planning, the need for a unified foreign policy and diplomacy, and the need for a unified military and defence strategy or what has become commonly regarded as the African High Command. Nigeria, in the pursuit of its national interests has over the period incorporated the most vital of these security threats in the principles governing its foreign policy.

In practice, Nigeria influences the trend of events in Africa. Indeed, it has become obvious that to continue to be functional, the Organisation of African Unity requires that Nigeria takes a definite and principled position on all issues because almost all observers of Nigeria's international relations monitor Nigeria's responses to global issues and they tend to be influenced by Nigeria's decisions and viewpoint. This fact was very clearly expressed on the question of recognition of the Polisario group in the OAU. Some will argue that black Africa is in need of leadership and Nigeria is the most logical country to play that r6le. Others will argue that Nigeria does not need to display extensive./ external involvement but must look inwards to develop a strong domestic base. Perhaps, a cursory examination of Nigeria's relative power position in global politics and its responses to threat perception on issues of regional integration, the problem of South Africa and food security will aid the understanding of Nigeria's aggressive, but halting strategies for dealing with the problems and defending its principles.

Beneath the surface turbulence of contemporary debate on foreign policy lies a broad base of consensus on Nigeria's most fundamental goals. Nigeria seeks a world in which it is at peace with other societies, especially its neighbours. Nigeria seeks a world in which nation states are free to pursue their own interests and destinies and in which the inevitable conflicts are firmly controlled and fairly amicably resolved.

But this aspiration cannot be operationalised without relative power, and self-reliance.

Power itself has been defined as the ability to do things and alter the environment. Foreign policy, in the same vein deals with a cluster of measures by which a country attempts to influence the international environment to its advantage to the extent possible - usually within its power. Consequently, it is axiomatic that the power of a nation will be a significant factor in determining the effectiveness of its foreign policy and the extent to which it can influence its external environment.

Thus, the power of a nation can be categorised into four: military, economic, technological, and ideological. Here we are especially concerned with the nexus between .military arid economic power and foreign policy which is easily understood. 
The power to pursue a foreign policy to the perceived advantage of a nation is a complex resultant of a cautious blend of economic, technological, ideological and military factors. There are no straight line correlations between increased power in any one area and its impact on the ability of the nation to be successful in foreign policy. In our system today there is considerable confusion on the relationship between power and foreign policy. This confusion, with regard to the meaning of power, its use and purpose pervading our society, has in fact led to the progressive loss in the legitimate use of power. In turn, this also tends to lead to a lack of perception about the dynamics of foreign relations without taking into account the most crucial and energising factors - namely, the power of nations.

For those who fail to take into account the power dynamics underlying international relations, foreign policy making is then reduced to a series of ad-hoc responses or ad-hoc initiative largely influenced by the perceptions of the situational contexts at present by the foreign policy establishment. It seems the only connecting thread of policy for them is the National Interest as formulated from time to time. For most of the states in the international system the factors of power are only external constraints to be taken into account in the -formulation of national interests and do not constitute components of their foreign policies.

In the present international system a nation that does not .adopt a foreign policy which fits in with its image as well as realities of its own inherent powers is bound to create avoidable trouble for itself.

Nigeria is seen by the external world as a nation with tremendous potential for great-power status. Its distinguishing characteristics place it in a special class in the community of nations. Nigeria, with a population of over 100 million, is the largest black nation in the world. This factor is critical for Nigeria because black peoples exist in the diaspora and in most other political centres of the world where they exist at the bottom rung of the economic ladder. Relative to other black African states, Nigeria has one of the highest gross domestic products on the African continent. By virtue of its large population in Africa and the amount of economic resources it is capable of mobilising, it seems inevitable that it should be a major factor in the determination of events on the African continent. A foreign policy, therefore, which takes into account power factors both nationally and externally has to be anchored on a planned augmentation of the power of Nigeria as a whole and has to interact with national security policy, national economic development policy and national social and political development policy.

If foreign policy is to be based on a small and mini-nation syndrome, there would be no need for these achorages which can be left entirely to the foreign policy establishment. But if it is to be based on the projection of a nation's power in the international arena and on the formulation of strategy of continually optimising that power in the interplay of international forces, then it has to be based on an inte- 
grated policy formulation that draws in as its inputs all policies which; contribute to the power of the nation. In today's context this is the choice facing the national leadership.

It is perhaps necessary that we should this point examine those fundamental objectives of Nigeria's foreign policy which constitute its national interest. This is based on the assumption that Nigeria's foreign policy reflects its basic national convictions, the enduring values to which it is dedicated. The purpose here is not to undertake a Four d' horizon of Nigeria's foreign policy objectives, but rather to point in broad strokes the basic principles underlying Nigeria's behaviour. We may then systematically apply these principles to specific issue areas.

This approach is adopted in the realization that foreign policy can best be analysed within a solid framework. The point of departure would naturally be the concept of national interest ${ }^{\prime}$ It is expected that a dole examination of this concept will perhaps help to explain why and how elements of Nigeria's national interests bear on its behaviour towards other states in the international system, hi a summary, these objectives as stated in the suspended 1979 Nigerian Constitution are:

(i) self-preservation of the country, that is, the defence and protection of her territorial integrity and of her people;

(ii) the defence and maintenance of the country's independence;

(iii) the economic and social well being of the people;

(iv) the defence, preservation and promotion of the ways of life, especially their democratic values;

(v) the enhancement of the country's standing and status in world capitals, especially Africa; and

(iv) the promotion of world peace.

The first major objective that constitutes the national interest is the defence of our sovereignty, our independence and our territorial integrity; that is to say, the stability of the country. The second major aspect of the national interest is the creation of the necessary political and economic conditions in Africa and in the rest of the world in such a way as to foster Nigeria's national self-reliance and rapid economic development. The achievement of this objective, we believe, would facilitate the independence of all African countries. Thirdly, it is a vital aspect of Nigerians national interest to promote equality and self-reliance in Africa and in the rest of the developing world. Fourthly, Nigeria must remain committed to the promotion and defence of social justice as well as respect for human dignity everywhere especially the dignity of the black man. Finally, Nigeria, as one of the 152 member-states of the United Nations Organisation, is permanently committed to the promotion of world peace and international security.

In the whole sphere of Nigeria's external relations, successive Nigerian governments have attached the greatest importance to an African centred policy, and have rightly crystallised the concept of Africa as the centre-piece of our foreign policy. This concept confirms the centrality of Nigeria's concern for continental affairs. Based on Nigeria's geopolitical, 'demographic, historic cultural circumstances, an African 
orientation is clearly indicated because its interaction with the world outside the African continent must be informed, and to a great extent, determined by the yearnings and legitimate aspirations of the people of Africa.

The challenge of our foreign policy since independence in 1960, has been to maintain consistency and continuity in not only projecting the fundamental principles of our national interest, but especially in espousing the African cause, and defending African interests in our external relations. It is this context that we must examine and understand Nigeria's unflinching support for the liberation struggles in Africa, its mediatory role in African conflicts and the 'good neighbour policy' toward its immediate neighbours in the West African sub-region.

South Africa poses the greatest threat to Nigeria's national interest. Thus, the major thrust of its Southern African policy is directed against the obnoxious system of apartheid and the complete decolonization of the African continent. Nigeria's Southern African policy has been guided by two principles: first, encouragement and support for the self-determination of African peoples still under colonial repression and the attainment of majority rule by black people. Second, a belief that the despicable system of apartheid must be eliminated, and the corresponding belief in the inalienable rights of all human beings, and in particular of all Blacks and African people throughout the world. Thus, during the past decade, Nigeria has consistently 'sounded a keynote in its external relations which consists in the "protection of the dignity of black peoples". This moral commitment to blacks was not conceived, nor does it exist, in a vacuum. The policy was formulated as the result of the practical conception of Nigeria's national interest. Nigeria shares a common destiny with blacks all over the world and any quest for the preservation of its own values, and aspirations was bound to ecompass the values, interests and aspirations of other members of the black world.

As the largest black African country with the greatest potential resources to mount a campaign of destabilization against the racists in Southern. Africa, Nigeria has consequently become a prime target for possible retaliatory attacks. Nigeria has attempted, however, to maximize the advantage inherent in its position as Chairman of the UN Special Committee against Apartheid. Nigeria has kept in continuous perspective before world opinion the monstrosity of the Apartheid system.

With regard to the sub region, one of Nigeria's principal priorities is to place relations with its neighbours on a more constructive footing. Nigeria's policy is based on close co-operation with its neighbours - because they share identical values of regional stability and peace.

Besides reinforcing relations with its immediate neighbours, Nigeria has over the years moved deliberately to reinforce bonds among ECOWAS member-states on a wider sub-regional scopes join ventures, trade, protocols, and agreements. 


\section{Annals of the Social Science Council of Nigeria}

Several years ago, Nigeria's former Head of State, General Obasanjo left no doubt where Nigeria stood on this issue. He asserted: "We in Nigeria believe that so long as one inch of African territory is occupied, we remain in bondage, and whenever any black or African is oppressed, we share the indignity." I reaffirm not only Nigeria's commitment to this issue as a fundamental tenet of our foreign policy, but also Nigeria's, constancy and consensus.

Against this background it appears that apartheid will be relentlessly embattled. From the Nigerian perspective, this means that Nigeria must assess its power capability and project possible alternative futures. The various dimensions of political, economic and strategic policies that Nigeria can pursue should be assessed in the light of the following scenarios:

\section{Nigeria and South Africa Anticipating Change}

As South Africa slides towards change, certain scenarios can be anticipated-. That is to say, the process of change can lead to various forms of government some of which may not suit Nigeria's interests. This conception is predicated on the fact that South Africa is a settler colony with a fairly large and well-entrenched white community who, faced with the inevitability of change, would strive for a place for themselves. The coercive power now at their disposal will be employed to serve that final purpose; and considering the adversity under which blacks are fighting, that possibility can be granted. In the unfolding change, at least three possibilities can be discerned thus: continuation of the present trend; a middle course policy; and a decisive overhaul of the present system.

\section{A Continuation of the Present Trend}

This entails a development under which apartheid would reform itself through incremental steps determined by so called reformed-minded whites. Fashioned after the style of limited power councils given recently to Indians and Coloureds (i.e. mixed race) white South Africa would seek reform through co-option and limited accommodation of some black leaders like those participating in the present "Homelands". This course will be a function of white resistance to change (which will be reflected in the behaviour of the apartheid government) and the real threat posed by insurgency. The whites will resist change for as long as they believe they can pacify or withhold domestic insurgency. However, the resultant government is likely to be unacceptable to Nigeria, the international community and more critically a large section of the black population in South Africa.

\section{A Middle Course}

South African whites currently label black insurgency as communist-inspired and this draws some attention in the West. With the most prominent black leaders either in jail or in exile, the apartheid govern- 
Achieving Security, Reducing Tensions:... 13

ment could move under pressure, to seek accommodation of those 'it considers "responsible black leaders." The difference between this strategy and the first is that where, as in the former, change is white-imposed and unilateral, the latter will be given a semblance of dialogue and negotiations under an internal conference. This aspect and Western status quo instinct might enable such a South African government to get some international recognition and probably divide African States. The objective of the whites would then be to decapitate existing black organisations and establish in their place a beholden few who will not seriously contest their power. Further, this would also conveniently divide black opinion and resistance.

Faced with a situation like that Nigeria will be at pains to take any steps that threaten to expose it as a collaborator. Besides, at this stage there will still be a rump of black opposition directed against a mixed government claiming legitimacy.

\section{A Decisive Change}

This anticipates a situation where the current black struggle will heat up to a level that will render any stop gap measures untennable. The most preferable of all other possibilities from the African and black perspectives, this scenario anticipates a system of government in reformed South Africa that has come about as a result of conventional constitutional procedures in which all interested parties actively participated. Unlike a situation where whites undertook reforms at their own pace and convenience, this option will entail an all embracing approach in a manner fully cognizant of non-white demands such as equal participation with one man one vote.

As it unfolds, this scenario is likely to bring along some residual complications. Confronted with a situation of apartheid in tatters, the prevailing unity among non-whites may fade once the various groups begin to assert themselves more wilfully to promote their chances in a reformed or post-apartheid South Africa. Thus, instead of blacks contesting for election under a unifying personality like Mr. Nelson Mandela, there may well be the ANC, PAC, Chief Bothelezi's Inkatha, something out of the amorphous VDF and some manouvres from the present leaders of the Bantustans like Chief Lucas Mangope or Kaiser Matanzima. The Indians and other mixed races may then go their own ways. White voting will endure the new times along a line similar to today's while the extreme racists increase their gains. Apart from the lure of power, the disintegration is also likely to be induced by white initiative through the electoral process and demarcation of constituencies with the sole objective of breaking up black advantage in numbers. Such adjustments will allay the fears of minorities, like the Indians and affluent coloureds, the whites would like to co-opt into their ranks. The currently enforced distribution of population along racial and ethnic lines shall be helpful for the whites in this regard. 


\section{Annals of the Social Science Council of Nigeria}

\section{The Namibia Phase}

As a prelude to the third scenario above, white South Africa could 'try to experiment change on its psychology by granting full independence to Namibia. The linkage of domestic political conditions to Namibia is one of the options available to apartheid South Africa to delay the final grand change at home and stave off any potential rift among the whites.

\section{Nigeria and Reformed/Post-Apartheid South Africa (Azania)}

An enduring relationship with a new South Africa is possible only under conditions of decisive change within South Africa. Any step(s) short of that will surely entail further complication of certain factors like sections of the black community contending the legitimacy of an emergent government which Nigeria can hardly ignore.

Even where change is deemed to be fair and just, a reformed South Africa could still pose for Nigeria certain problems, however mild. The white community by its political mind-set and cultural identity with the West will constitute a built-in guidance system in a reformed South Africa. Thus, it can be "conceived that under that influence (which is substantial as a result of the advantages it bestowed on whites under apartheid) South Africa is likely to be centre right and pro-West in spite of references to nonalignment. This means that on balance South Africa's foreign and defence policies will still favour Western interests. Should that be the case Nigeria-South Africa relations will acquire a certain angle from the perspective of Pretoria's western axis. This will be particularly so if Nigeria remains unequivocal in its non-alignment, pan Africanist stance. South Africa might then hesitate about certain forms of military co-operation lest it hurts Western designs. Trade and other forms of civil co-operation can still continue apace, but an element of rivalry will be inevitable

This prospect is contingent on white's influence holding sway in reformed South Africa with their mind-set intact. It can be altered, however, if black's build-up their own counteveiling influence in the system as time goes on. The process of erosion will be easier for the blacks if the danger of not doing so has been acknowledged even at this stage so that optimum attention will be paid to building up black expertise in tandem with the nationalist struggle.

Nigeria's role in establishing the foundation of future relations with reformed South Africa starts here. In practical terms, there is already such a relationship in the form of active support for black aspirations in South Africa. What is required is a conceptual framework. The conception being that existing policies will be pursued not as a short-term measure but as a way whereby Nigeria presents itself as structurally relevant to the processes of development and change in the region as a whole. 


\section{Achieving Security, Reducing Tensions:... 15}

\section{Nigeria, South African and South Atlantic 'Insecurity'}

During World War II, the South Atlantic played an important role in the strategy of the allied forces. In recent times it has become increasingly vulnerable to threats from the big powers. The continuing racial crisis in Southern Africa and the protracted conflict between Argentina and Great Britain over the Malvinas suggest that the area has become a focus for attention. Apart from the geographic importance of the: South Atlantic itself the west coast of Africa contains considerable oil deposits. There are abundant fish resources in this area, rendering it attractive' for some big powers like the Soviet Union to maintain a maritime presence there. In addition to oil and fish, the South Atlantic also contains some of the world's largest deposits of scarce minerals like gold, manganese, chrome, diamond, bauxite and uranium. The low defence capability of the states along, the coast of West Africa has enhanced the relative capability of the more advanced states, namely Brazil, Argentina and South Africa.

What this means is that the emerging environment in the Southern Seas requires that African nations, especially Nigeria, fully understand the strategic threats to their security and territorial interests. Already, western and pro-western powers are demonstrating increasing attention to the politico-military threats to the security of the, oil flow in the Southern Seas, at least, until economically viable alternatives to the Gulf Oil can be found. In practice, this means that Western capabilities are being improved for deploying into the South Atlantic Ocean.

\section{IV}

One reaction to the Cuban presence in Angola was the revival of the idea of an alliance of the Southern Cone countries led by the United States and designed to incorporate racist South Africa. This alliance is meant to be a logical extension of and counterpart to NATO. It is believed that a secure South Atlantic would necessarily rely on control over the Cape of Good Hope and the 'Narrous" from North-Eastern Brazil to West Africa.

It was envisaged that the key nations in SATO would be Brazil, South Africa, Argentina with the United States as principal partner. Given the new development of a crack in diplomatic relations between Argentina and South Africa, it is possible that SATO as it is presently conceived might be in some disarray.

\section{Reflections - The Role of the Navy}

It has been established that the central purpose of Nigeria's policy is the security of Nigeria. The question that arises is: "does Nigeria have any security concerns in the South Atlantic?" If so, what are Nigeria's security needs in the South Atlantic and its coastal water?

By virtue of its long ocean frontiers, Nigeria is a coastal state with an interest in the assertion of domestic jurisdiction and enforcement 


\section{Annals of the Social Science Council of Nigeria}

rights over its coastal waters. There is thus an urgent need for a South Atlantic surveillance and asserting of sovereignty in our territorial waters, and control over the economic zone that extends at least 200 miles out to the seas.

The frantically increasing militarization of the South Atlantic makes at least, 1,500 miles of Nigeria's coast very vulnerable to great power manipulation. This vulnerability is even more pronounced when we realise that none of the littoral African states has a sizeable naval force. In view of this visible threat, it is imperative that we re-examine the role of the navy and reinforce its capability to deal with any external threat. Consonant with some of the analytical foreign policy tools that I have utilised in this paper I believe that the most credible point of departure toward re-examining the role of the navy is to revolutionise its intelligence units' A new naval orientation must begin from the irreducible fact that tensions in the South Atlantic pose a threat to Nigeria's security and Nigeria's naval forces must be equipped with a credible intelligence unit that is capable of seeking and processing information about activities in its environment and any other areas of direct relevance to our security. This naturally leads-us to a consideration of the type of navy that Nigeria needs to develop in the years to come to provide the sort of security environment in which Nigeria may live in peace and progress. The composition of such types of ships and aircraft should make up such a fleet is best left to the planners at the NAVAL HEADQUARTERS to review and decide from time to time. What is becoming increasingly clear and indicated is that the navy has developed along the lines of an ocean navy in tune with our self perception. By that is meant the ability to project our military clout anywhere in the South Atlantic should the need arise.

It is true that serious questions have been raised about the ability of Nigeria's industrial base to produce, and the ability of the Nigerian navy to efficiently manage such an expansion. Critics wonder if an expanded navy and marine corps capable of achieving maritime superiority - in concert with our allies and sister services - are affordable and whether a deteriorating industrial base will succeed in carrying out a reformed naval orientation.

The reaction of this writer is that achieving Nigeria's political goals depends on a credible defence and deterence. We need this security which assures that the people of Nigeria will be safe from external harm and thus free to live in peace to the fullness life affords, free to obtain a fair share of the world's resources needed for both survival and growth. In addition, Nigeria's economic well-being is continually more dependent on overseas trade and very vulnerable to distant political development. We may have to rely on the strength, mobility and versatility of the navy. The navy can emphasize the protection of the sea line of communication.

We must also examine the role of the navy as a vital arm of Nigeria's diplomacy. A nation's credible defence rests on the capability to vividly demonstrate its economic and military might beyond its borders in 
peacetime. Consequently, the role of-a navy is not limited to the execution of important missions in armed combat.

The Navy constitutes an instrument of policy - an important support of diplomacy. In this regard, it is timely for the Nigerian navy to embark on a naval tour of the Southern Cone countries of Latin America - Brazil,, Argentina, Uruguay, Paraguay, to explode the myth prevalent in the area about the Blackman's constructive ability. This strategy will effectively boost the morale of the blacks in the Latin America Diaspora. Besides, it is purely a political application, of NAVAL POWER - the use of Nigerian ships and Nigerian naval officers as symbols, rather than direct instruments of power! In the final analysis, the funds available will decide how far and how fast Nigeria can develop an ocean-oriented fleet, but the navy must first be clear in its mind as to its objectives.

For a long time, Nigeria's economic activity has been structured primarily around a few primary products; and it has largely depended on the export of petroleum. The implication to national defence and security of an economy that is over dependent on one commodity for the provision of about $90 \%$ of its national income is quite evident. Since the growth in world prices of petroleum in the mid-seventies, the agricultural sector, which had earlier sustained a relatively healthy, economy, registered a steady decline and petroleum export became the main-stay of the economy. An indication of the strategic importance of oil to the Nigerian economy is given by these figures. In the Second National Development Plan (1970-1974) ££3 billion was earmarked for its finance; in the Third National Development Plan (19.5-1980) it was to be financed by $\$$ f30 billion (later on enlarged to $\$ 343.3$ billion after the 1974 re-adjustment of global oil prices). The Fourth National Development Plan (1981-1985) was designed to cost \$f 82 billion with the expectation of higher income from oil.

If the outlet for petroleum had been diverse, the vulnerability of the dependency would have been less. Nigeria exports most of her oil to the Western European countries and the United States. The danger of this factor lies in the effect which a concerted decision by the main buyers can have on the national economy. In fact, part of the problem that faces Nigeria today is related to the decline in the proportion of Nigerian oil in the United States petroleum import, and the fact that whereas in the late seventies and early eighties, Nigeria was the fourth largest supplier of petroleum to the U.S., she is currently the eleventh. External 'powers can radically alter the power position of the state by a simple decision to buy more or less of its petroleum, a decision, which can affect the rate of growth and the social and political climate of the country concerned.

Another dimension of the strategic implication of economic dependence is the increased vulnerability of a state that is dependent on the 


\section{Annals of the Social Science Council of Nigeria}

external environment for food. Food is a highly volatile weapon which can be effectively used to create instability in another state, with lit [or no cost to the user. An unemployed person who has access to reasonably priced food is less likely to engage in social revolt compared to an unemployed that is hungry. In the immediate post independent era up to the mid-seventies, Nigeria was largely an agrarian country -earning 70.8\% of her income from exports through trade in agricultural commodities. Agriculture constituted $63 \%$ of the GDP in 1960 but by 1981, it was only 23\%. The country's food import bill rose from. $\$ \$ 508$ million in 1964 to $£ £ 1.86$ billion in 1981. Food is a most important instrument of war. A potentially powerful country that depends on external sources for food can always be forced to abandon its national objectives through the denial of import of food whereas a country that is self sufficient in food can withstand several months of blocade or denial of external -access to food. Self-sufficiency in the production of food is, therefore, an underlying foundation for an effective national defence policy.

The economic threat that faces the country .can be, contained through an integrated structural reorganization of the national economy. The structural reorganization must be designed to create jobs through industrialization of the national economy utilizing, as much as is economically practicable, the local raw material potential so that there will be a backward integration of such industries to the larger economy. Secondly, the resource base has to be expanded to enable the country produce agro-based and industrial commodities for export. The foreign exchange component of industrial and agricultural exports of the national economy must be increased in relation to the share of oil exports. This is all the more important, not only because of the undependable nature of the oil market but also because oil is a deple table asset. Nigeria's oil reserve, it has been estimated ${ }^{1}$ can be exhausted within the next twenty years, if the present rate of production is maintained, by which time, Nigeria will become a net exporter of more expensive OPEC oil. For as long as oil income constitutes an important proportion of the national income, the value of the industry to the larger economy can be enhanced through the development of petrochemicals, gas condensate, and liquefied natural gas industries. Investment in these sectors will create a spin-off of several industries utilizing the outputs in these sectors. Over the period, Nigeria has mobilised efforts both at the domestic and regional fronts to alleviate some of the economic problems as they affect her and other African countries. Nigeria has embarked, in concert with other African countries, on strategies for self-reliance. This is illustrated in Nigeria's

primacy in the intensification of South-South co-operation and its regional integration efforts in ECOWAS and the Organisation of African States.

The achievements of the ECOWAS since its inception on May 28, 


\section{Achieving Security, Reducing Tensions:... 19}

1975, are not particularly remarkable in spite of the constant desire for integration expressed by the political leaders in the sub-region. A number of measures in the areas of trade liberalisation, free movement of persons, non-agression, and telecommunications have "been adopted but for varying political and economic reasons most of these have not been fully implemented by member states. Moreover, the irregular contributions to the fund and the community secretariat by the member states have hampered the effective operation of both institutions.

One of the basic critical issues in the ECOWAS is the lack of political will which represents a crucial factor in the process of integration. The basic element in the creation of political will is dissatisfaction with the existing state of affairs, and the expectation of benefits to be derived from the community. These benefits are not necessarily confined to those of a wholly material and tangible nature. They are related - if they are to provide a basis for significant political pressure-to the central purpose of-any organised political community, namely, security (internal and external) and welfare. The strength of the political will based on such expectation that a group develops will clearly be a major component in its capacity to move towards union. The way in which the flowing demands for union evolve over time is also of crucial importance. It cannot be assumed that they will necessarily remain constant in strength or direction, and should they weaken or be focused on increasingly divergent objectives the process of integration is likely to come to a halt or experience serious tensions.

In the ECOWAS, the flowing demands for union has been charactised by weakness. The pressures for integration have diminished as the original concerns that gave birth to the process recede to the background. The argument for the elimination of colonial domination, potent in the early 1960 s, has waned.

The demand for security, muted in 1979 and 1981 in the forms of non-aggression pact and Mutual Defence Pact respectively, has not been strengthened. The protocol on non-aggression pact has only been ratified by six member states. The Mutual Defence Pact, even though realistic in the face of constant border disputes and irredentism of most African states, has not been vigorously pursued for ratification since the idea is averse to the Francophone states which perceive a more respectable national security in the context of the several military co-operation arrangements with metropolitan France. These pacts enable France to intervene militarily in Francophone states in the event of external aggression, as evidenced in the intervention of her peacekeeping force into Chad in 1979.

Furthermore, progress in the ECOWAS has been undermined by the operation of rival organizations notably, the CEAO. The CEAO is far ahead of any of its other African counterparts. Ft has established a 
common fund for .development, a communal institute for education arid training and a Regional Co-operation Tax. Indeed, as a viable organization it shares with the ECOWAS the major external financial aid to the region from the United Nations and its agencies. In addition to this, it also benefits from financial support and technical assistance from the French government which backed its formation and saw it as a framework for, the promotion ,of its (economic and political interests in the sub-regions.

Regional integration is a complex and difficult process; It requires the implementation of its provisions and absolute commitment of the participating states if it is to survive and achieve its Objective. The dismal performance of the ECOWAS so far is not necessarily a cause for despair to regional integrators. The reasons for the formation of the ECOWAS ten years ago are still valid today. The case for rapid economic development is salutary in a sub-region where most states had suffered in varying degrees from the adverse impact of global economic recession and bouts of Sahelian droughts.

Political will is an essential factor which is fundamental to the consolidation of the ECOWAS. There should be sustained commitment to it at the highest governmental level based on the understanding, that substantial benefits could only accrue to the region over along period. The less the political will, the more the tendency for ECQWAS to stagnate.

The economic importance of the ECOWAS to Nigeria cannot be underestimated .even though the country may be experiencing economic difficulties, Nigeria must fully address itself to the question of political leadership within: ECOWAS if the :Community is to attain set objectives. It must lay emphasis not only on the implementation of infrastructural measures but also on, the adoption and implementation of those; measures which are fundamental to meaningful integration, especially those on monetary integration .and integrated development, Also, measures on agricultural development are important in a sub-region confronted with critical food shortage.

The 1980 Lagos Plan of Action aimed at the promotion of accelerated economic development in Africa through (a) reliance on Africa's huge resources; and (b) the promotion of economic integration. Five years after the adoption of the Lagos Plan of Action however, we are particularly distressed by the fact that little progress has been achieved.

National development plans as well as annual budgets have in most countries, tended to perpetuate and even accentuate the dependency of our economies through overreliance on foreign resources and misallocation of domestic resources with reduced shares for such high priority areas as agriculture, manpower and industry and massive expenditure on foreign consumer goods. Full knowledge of the natural 


\section{Achieving Security, Reducing Tensions;... 21}

resource base and training of various types of skills for the exploration and use of natural resources have not received the attention they deserve to ensure self-sustained development.

Economic integration schemes, clearly a corollary of national and collective selfreliance and self-sustained development, have not progressed enough to ensure maximum growth and development and enable the African region to play a more important role in international affairs.

The basic problems in the implementation of the Lagos Plan of Action are two fold: (a) the colonial economic structures inherited by most African countries and the failure to procure fundamental changes (b) the worsening of the international economic environment especially since 1980. The most important factors here include: (i) the collapse in commodity prices, (ii) a stagnation and decline in official development assistance (ODA) in real terms (iii) unprecedented high interest rates; and (iv) the shift to a regime of sharp fluctuations of interest rates and increased protectionism.

\section{Conclusion}

The worsening international economic situation and rapid deterioration in the economies of most African countries demand that the strategies enumerated in the Lagos Plan of Action are basic to economic recovery and sustained development.

In this regard, effective measures must be taken to alleviate Africa's debt burden and to arrest the deterioration in trade and consequent reduction in export-earnings for debt servicing. The internal markets of most African countries are far too small to justify the optimum operation of large scale industries with minimum cost of production. Given the present level of industrial development in these countries specialization in production could be arranged to ensure efficient production.

At the national level, effective mechanisms for national debt management and rationalization must be established. Non-productive and non-essential activities that do not help in the repayment of loans and which constitute drains on foreign exchange resources should be closed down.

The increasing protectionism of the industrially developed countries' stresses further the need for regional integration.

Sufficient funds should be made available for their operation of component states which must be encouraged to implement agreed measures.

It may be safe to assert that existing regional arrangements in spite of their limitations, are serving useful functions within the constraints of sub-imperialist interventions in the region. While they have not been totally effective, the constantly changing international environment, demand not more conflict, but appropriate measures for managing the 


\section{Annals of the Social Science Council of Nigeria}

complexities of development and security. The highest priority for Nigeria and Africa is to evolve feasible strategies in consonance with their national or continental interests and which would be conducive to self-reliance and self-defence. Nigeria will continue to play a dynamic role in the African setting, thereby increasing the capacity of African countries in North-South dialogue or South-South relationship. Nigeria's achievements in the OAU and ECOWAS can be further enhanced through dynamic intensification of concerted African efforts.

\section{References}

Imobighe, T. (1980) "An African High Command: The Search for a feasible strategy of Continental Defences," African Affairs, 79, 214-254.

Legun, C. (1962) Pan Africanism: A short Guide Connecticut: Gleenwood Press., p.14.

Nyafi, VM. (1977) "South African Imperialism in Southern Africa", Nigerian Journal of International Affairs, Vol.3,Nos. 1 \& 2, 55-56.

Samater, SJ5. (1979) 'The New Rivalry in Africa: America and Russia in the Recent Crisis of the Horn," The Pan-Africanist, No. 8, 3740.

Waller stein, I. (1967) Africa: the Politics of Unity, New York: Vanty Books, p.10 